\title{
HUBUNGAN SOSIAL MAHASISWA PERANTAU DALAM PAGUYUBAN JONG JAVA SEBAGAI SUMBER BELAJAR SOSIOLOGI DI SMA (STUDI KASUS PAGUYUBAN JONG JAVA DI UNDIKSHA )
}

\author{
Eky Hardiyana1, Dr. I Ketut Margi, M.Si ${ }^{2}$, I Gusti Arya Suta Wirawan, M.Hum \\ M.Si ${ }^{3}$
}

Jurusan Pendidikan Sosiologi

Universitas Pendidikan Ganesha

Singaraja, Indonesia

\begin{abstract}
e-mail \{hardiyana1234@gmail.com.ketut.margi@yahoo.co.id. arthasuta@gmail.com\}
\end{abstract}

\begin{abstract}
Abstrak
Penelitian ini bertujuan untuk mengetahui (1) Latar belakang mahasiswa perantau dari jawa untuk membentuk Jong Java di Undiksha, (2) Hubungan sosial yang terjadi antar mahasiswa perantau Jawa di Undiksha yang tergabung di dalam Jong Java, (3) Peran Jong Java terhadap mahasiswa perantau di Undiksha, (4) Aspek-aspek Paguyuban Jong Java yang dapat digunakan sebagai sumber belajar di SMA. Pendekatan yang digunakan menggunakan pendekatan deskriptif kualitatif. Lokasi penelitian dilakukan di Universitas Pendidikan Ganesha sebagai tempat pelaksanaan kegiatan, Undiksha terletak di Kota Singaraja, Kabupaten Buleleng, Bali. Teknik penentuan informan menggunakan Random Sampling. Teknik pengumpulan data melalui observasi, wawancara, dan dokumentasi. Pengecekan pengabsahan data menggunakan triangulasi sumber dan triangulasi metode dan Teknik analisis data menggunakan analisis interaktif. Hasil penelitian menunjukan bahwa, (1) Latar belakang Paguyuban Jong Java memiliki 2 faktor yaitu: faktor kegelisahan dan kebutuhan, (2) Hubungan sosial mahasiswa yang tergabung pada Paguyuban Jong Java terjalin dengan baik hal ini dapat dibuktikan pada kegiatan-kegiatan seperti memperingati hari besar nasional dan hari besar islam (3) peran Jong Java yaitu sebagai tempat berkumpul dan tempat untuk berdiskusi serta sebagai pemenuhan kebutuhan (4) Aspek-aspek dalam paguyuban Jong Java yang digunakan sebagai sumber belajar yakni terdapat pada 3 ranah yaitu : ranah kongnitif, afekti dan Psikomotorik.
\end{abstract}

Kata Kunci : Mahasiswa perantau, paguyuban dan sumber belajar

\begin{abstract}
This study aimed at determining (1) background of migrant students from Java to shape Jong Java in Undiksha, (2) social relationship that occurred between Javanese migrant students in Undiksha who are members of Jong Java, (3) Role of Jong Java to migrant students at Undiksha, (4) Aspects of Paguyuban Jong Java that could be used as a source of learning in high school. The approach used is a qualitative descriptive approach. This study was conducted at the Ganesha Educational University as the place to conduct the activities; Undiksha was located in Singaraja City, Buleleng Regency, Bali. The technique of determining informants was using Random Sampling. The technique of data collections were observation, interviews, and documentation. Checking the validity of the data was using triangulation source and method triangulation. This study used interactive analysis as the analysis technique. The results of study show that, (1) the background of the Jong Java has 2 factors: anxiety and needs factors, (2) the social relationship of students who are affiliated with the Jong Java are well, this can be proven in the activities including celebrating holidays. national and Islamic holidays (3) the role of Jong Java is as a gathering place and a discussion place as well as need accomplishment (4) aspects of the Jong Java that are used as learning resources that involve 3 domains namely: cognitive, affective and Psychomotor.
\end{abstract}

Keywords: student migration, Paguyuban and learning resources. 


\section{PENDAHULUAN}

Secara geografis Bali terletak di sebelah Timur pulau Jawa. Bali tidak hanya terkenal dengan tempat-tempat wisatanya saja akan tetapi juga terkenal dengan masyarakatnya yang sangat menjunjung tinggi nilai adat istiadat sehariharinya. Di Indonesia terdapat banyak perguruan tinggi, adapun perguruan tinggi Negeri yang ada di Indonesia menurut dikti berjumlah 155 perguruan, sedangkan perguruan tinggi swasta berjumlah 100 perguruan. Pada umumnya, jika dilihat dari sebagian banyak perguruan tinggi pasti memiliki mahasiswa-mahasiswi yang berasal dari lokasi yang berbeda dari daerah atau tempat Universitas, hal semacam ini sering disebut dengan mahasiswa perantau. Maka dari itu sebagian besar mahasiswa yang melanjutkan studi perkuliahan identik dengan budaya merantau. Merantau sendiri dapat diartikan sebagai orang yang meninggalkan teritorial lama dan pergi menempati teritorial baru. Di tanah rantau mereka mencari mata pencaharian baru untuk memenuhi kebutuhan hidup mereka. Keadaan merantau telah menjadi budaya hidup beberapa suku yang ada di Indonesia, adapun suku-suku bangsa yang memiliki budaya merantau, yakni Suku Batak, suku Jawa, suku Bugis, suku Madura, suku Minangkabau dan sukusuku lainnya. Hal ini sejalan dengan pengertian yang tercantum dalam Kamus Besar Bahasa Indonesia edisi ke empat (KBBI, 2008: 1143) mengatakan bahwa, "Merantau memiliki arti berlayar atau mencari penghidupan di tanah rantau atau pergi ke negeri lain untuk mencari penghidupan, ilmu, dan sebagainya"

Di Bali sendiri terdapat beberapa Universitas-universitas terbaik yang bisa menjadi tujuan bagi calon mahasiswamahasiswi dalam mencari ilmu, dan di Bali terdapat dua perguruan tinggi Negeri yakni Universitas Udayana Denpasar dan Universitas Pendidikan Ganesha atau yang biasa di kenal dengan Undiksha bertepatan di Kota Singaraja, sedangkan untuk perguruan tinggi swasta yang ada di bali yaitu Universitas Dwijendra, Denpasar, Universitas Hindu Indonesia,
Denpasar, Universitas Mahasaraswati Denpasar, Denpasar, Universitas Mahendradata, Denpasar, Universitas Ngurah Rai, Denpasar, Universitas Panji Sakti, Singaraja, Universitas Pendidikan Nasional, Denpasar, Universitas Tabanan, Kediri, Tabanan, Universitas Warmadewa, Denpasar, Universitas Dhyana Pura, Badung. Universitas-universitas tersebut tersebar di berbagai Kabupaten/Kota yang ada di wilayah Bali dan perguruanperguruan tinggi tersebut pasti memiliki mahasiswa yang berasal dari luar daerah atau mahasiswa rantau, salah satunya yakni di Universitas Pendidikan Ganesha (Undiksha) tepatnya di kota Singaraja, Kabupaten Buleleng, Bali. Undiksha banyak diminati oleh mahasiswa dari Bali maupun luar Bali, hal ini bisa dilihat dari banyaknya mahasiswa yang kuliah dengan menggunakan sepeda motor dengan nomor polisi yang bukan dari Bali misalnya dari Banyuwangi, Bondowoso, Lombok, dan lain-lain, serta sering kita jumpai banyaknya mahasiswa yang ketika berkomunikasi dengan temannya tidak menggunakan bahasa Bali melainkan menggunakan bahasa luar Bali atau menggunakan bahasa daerah mereka masing-masing, seperti bahasa Jawa, Madura, Sasak, Batak, Papua, Sunda dan bahasa yang lainnya.

Banyaknya mahasiswa yang berasal dari luar Bali, menyebabkan munculnya organisasi-organisasi atau Paguyuban sebagai tempat berkumpul dan berdiskusi dengan teman se-daerah. Salah satunya yakni Paguyuban Jong Java, Paguyuban merupakan sebuah perkumpulan orangorang yang memiliki kesamaan etnis atau daerah. Biasanya ini terbentuk karena adanya perkumpulan anak-anak rantau yang berada dalam suatu tempat atau wilayah yang sama, seperti yang dilakukan oleh mahasiswa-mahasiswa Jawa, sebab dirasa banyak mahasiswa yang berasal dari pulau Jawa sehingga mereka muncul inisiatif untuk membentuk suatu Paguyuban yang anggotanya merupakan mahasiswa-mahasiswi berasal dari pulau Jawa yang diberi nama Paguyuban Jong Java dan Paguyuban tersebut sebagai Paguyuban yang bersifat 
ekstra kampus atau non-formal. Di Undiksha tidak hanya terdapat Paguyuban Jong Java saja, akan tetapi terdapat kelompok Paguyuban lain seperti HIPMAL (himpunan mahasiswa Lombok), IMSU (ikatan mahasiswa Sumatera), dan organisasi-organisasi lainnya intra maupun ekstra.

Paguyuban Jong Java di Undiksha terdiri dari kelompok-kelompok kecil yang terbagi dalam segi unsur kedaerahan atau kabupaten, seperti: JABODETABEK, Jong

Tabel : 1.1 Jumlah Anggota

Jong Java

\begin{tabular}{|c|c|c|}
\hline $\begin{array}{l}\mathbf{N} \\
\mathbf{0}\end{array}$ & $\begin{array}{c}\text { Provinsi/Kabu } \\
\text { paten/Kota }\end{array}$ & $\begin{array}{c}\text { Ju } \\
\text { mla } \\
\text { h }\end{array}$ \\
\hline & $\begin{array}{l}\text { JABODETAB } \\
\text { EK }\end{array}$ & \\
\hline 1 & Bandung & $\begin{array}{c}2 \\
\text { Ora } \\
\text { ng }\end{array}$ \\
\hline 2 & Bogor & $\begin{array}{c}3 \\
\text { Ora } \\
\text { ng }\end{array}$ \\
\hline & Banten & $\begin{array}{c}4 \\
\text { Ora } \\
\text { ng }\end{array}$ \\
\hline & Jawa Tengah & \\
\hline $\begin{array}{l}1 \\
.\end{array}$ & Purworejo & $\begin{array}{c}2 \\
\text { Ora } \\
\text { ng }\end{array}$ \\
\hline $\begin{array}{l}2 \\
.\end{array}$ & Pati & $\begin{array}{c}4 \\
\text { Ora } \\
\text { ng }\end{array}$ \\
\hline 3 & Wonogiri & $\begin{array}{c}2 \\
\text { Ora } \\
\text { ng }\end{array}$ \\
\hline $\begin{array}{l}4 \\
.\end{array}$ & Purwokerto & $\begin{array}{c}1 \\
\text { Ora } \\
\text { ng }\end{array}$ \\
\hline 5 & Karanganyar & $\begin{array}{c}1 \\
\text { Ora } \\
\text { ng }\end{array}$ \\
\hline
\end{tabular}

Paguyuban Jong Java merupakan salah satu bentuk dari kelompok sosial, adanya suatu kelompok sosial tidak lain
Jateng, Jong Tuban, Jong Lamongan, Jong Banyuwangi, Jong Probolinggo, Jong Bondowoso, Jong Situbondo dan lain-lain.

Adapun jumlah data anggota yang tergabung di dalam Paguyuban Jong Java berjumlah 322 anggota, data tersebut merupakan data sekunder berdasarkan hasil survei keanggotaan pada tahun 2017

\begin{tabular}{|c|c|c|}
\hline & Jawa Timur & \\
\hline 1 & Tuban & $\begin{array}{c}20 \\
\text { Ora } \\
\text { ng }\end{array}$ \\
\hline 2 & $\begin{array}{l}\text { Lamongan, } \\
\text { Gresik, } \\
\text { Bojonegoro }\end{array}$ & $\begin{array}{c}78 \\
\text { Ora } \\
\text { ng }\end{array}$ \\
\hline $\begin{array}{l}3 \\
.\end{array}$ & $\begin{array}{l}\text { Surabaya, } \\
\text { Sidoarjo }\end{array}$ & $\begin{array}{c}6 \\
\text { Ora } \\
\text { ng }\end{array}$ \\
\hline 4 & Blitar, Nganjuk & $\begin{array}{c}5 \\
\text { Ora } \\
\text { ng }\end{array}$ \\
\hline 5 & $\begin{array}{l}\text { Pasuruan, } \\
\text { Jember }\end{array}$ & $\begin{array}{c}10 \\
\text { Ora } \\
\text { ng }\end{array}$ \\
\hline 6 & Probolinggo & $\begin{array}{c}27 \\
\text { Ora } \\
\text { ng }\end{array}$ \\
\hline 7 & Situbondo & $\begin{array}{c}5 \\
\text { Ora } \\
\text { ng } \\
\end{array}$ \\
\hline 8 & Bondowoso & $\begin{array}{c}5 \\
\text { oran } \\
\mathrm{g} \\
\end{array}$ \\
\hline 9 & Banyuwangi & $\begin{array}{c}150 \\
\text { Ora } \\
\text { ng }\end{array}$ \\
\hline \multicolumn{2}{|c|}{$\begin{array}{l}\text { Jumlah } \\
\text { Keseluruhan }\end{array}$} & $\begin{array}{c}322 \\
\text { Ora } \\
\text { ng }\end{array}$ \\
\hline
\end{tabular}

Sumber: Di olah dari data survei deng form anggota Jong Java Tahu

pasti terdapat hubungan sosial, Pada dasarnya setiap individu adalah makhluk sosial yang senantiasa hidup dalam 
lingkungan masyarakat, baik itu lingkungan fisik maupun lingkungan psikologis yang di dalamnya saling mempengaruhi antara individu satu dengan individu lain. Salah satu ciri bahwa kehidupan sosial itu ada, yaitu dengan adanya interaksi, interaksi sosial terjadi karena adanya hubungan timbal balik antara individu satu dengan individu lain, individu dengan kelompok maupun kelompok dengan kelompok yang terdapat di dalam lingkungan masyarakat. Seperti yang dijelaskan oleh salah seorang ahli sosial Gillin dan Gillin (dalam Soekanto, 1994:67-68), "Interaksi Sosial adalah hubungan-hubungan sosial yang dinamis dan menyangkut hubungan antar individu dan kelompok atau antar kelompok".

Pemahaman sumber pembelajaran yang ada pada materi Sosiologi masih terpaku pada guru dan buku sumber, sehingga siswa kurang memahami keadaan yang ada dilingkungan, padahal sudah banyak terjadi peristiwa-peristiwa sosial di masyarakat yang dapat dijadikan sebagai sumber belajar siswa dalam proses pembelajaran, seperti Paguyuban Jong Java di Undiksha, Paguyuban ini dapat di jadikan sebagai sumber belajar tentang materi individu, kelompok dan hubungan sosial melalui aspek-aspek apa saja di dalam Paguyuban yang dapat di jadikan sebagai contoh maupun sebagai sumber belajar.

Berdasarkan paparan di atas, peneliti akan membuat hasil penelitian yang berjudul "Hubungan Sosial Mahasiswa Perantau dalam Paguyuban Jong Java Sebagai Sumber Belajar Sosiologi di SMA (Studi Kasus Paguyuban Jong Java di Undiksha)".

\section{METODE}

Pengumpulan data dalam Penelitian ini menggunakan rancangan penelitian deskriptif kualitatif yang digunakan untuk memperoleh informasi tentang Hubungan Sosial Mahasiswa Perantau dalam Paguyuban Jong Java Sebagai Sumber Belajar Sosiologi di SMA (Studi Kasus Paguyuban Jong Java di Undiksha).Lokasi penelitian adalah Lokasi penelitian yang diteliti oleh penulis dilakukan di Universitas
Pendidikan Ganesha sebagai tempat pelaksanaan kegiatan, Undiksha terletak di Kota Singaraja, Kabupaten Buleleng, Bali. Hal ini sebab di Undiksha terdapat banyak mahasiswa yang berasal dari Jawa atau bisa dikatakan berasal dari luar Bali, dimana para mahasiswa mampu untuk membentuk kelompok yang berasal dari kesamaan daerah atau biasanya di sebut sebagai Paguyuban dan Paguyuban Jong Java ini menurut peneliti sangat bagus karena mampu menyatukan mahasiswa perantau asal Jawa yang memiliki berbagai perbedaan etnis, mulai dari etnis Jawa, Madura, hingga Sunda.

Teknik penentuan informan disusun melalui penelitian ini terdapat informaninforman tertentu yang dapat di jadikan sebagai sumber yakni informan kunci, seperti ketua Paguyuban dan pembentuk Paguyuban. Dalam hal ini teknik pengumpulan data yang di gunakan oleh peneliti yaitu menggunakan teknik random sampling.

proses pengumpulan data terhadap suatu penelitian yang akan penulis lakukan harus memiliki cara atau teknik untuk mendapatkan data atau informasi yang baik dan terstruktur serta akurat dari setiap apa yang akan diteliti, sehingga kebenaran informasi data yang diperoleh dapat dipertanggungjawabkan. Teknik pengumpulan data yang akan digunakan dalam penelitian ini, antara lain: observasi, wawancara mendalam dan studi dokumentasi.

Teknik penjaminan keabsahan digunakan secara terpisah, yang satu mendahului yang lainnya, bahkan dapat pula diterapkan secara konteks triangulasi data. Adapun bentuk triangulasi yang digunakan, tujuannya sama. Yakni mempertinggi kualitas keaslian data sehingga hasil penulisan yang didapat memiliki objektivitas yang lebih tinggi, diantaranya: triangulasi sumber dan triangulasi metode

Teknik analisis data yang paling sederhana dan banyak digunakan oleh peneliti kualitatif, yakni pengumpulan data, reduksi data, sajian data/display data dan penarikan kesimpulan. Analisis data interaktif ini selalunya merujuk pada 
konsep yang ditawarkan oleh Miles dan Hubberman (1992:15-19), yang terdiri dari kegiatan pengumpulan data, reduksi data (data reduction), penyajian data (data display), dan penarikan kesimpulan (drawing conclousion).

(1) Pengumpulan Data,

Pada tahap ini peneliti mencatat semua data secara obyektif dan apa adanya sesuai hasil observasi dan wawancara dan dokumentasi di lapangan.

(2) Reduksi Data

Proses seleksi dan klasifikasi data untuk disesuaikan dengan tema/topik penelitian.

(3) Sajian Data/Display Data

Data yang sudah direduksi, perlu disajikan dalam bentuk tulisan yang sistematik, disajikan dalam bentuk matrik, grafik atau tabel supaya mudah dilihat dan difahami hubungannya antara satu data dengan lainnya, sehingga memudahkan dalam penarikan kesimpulan.

(4) Penarikan Kesimpulan

Penarikan kesimpulan merupakan proses memaknai data melalui analisis korelasi, komparasi dan kontekstualisasi dengan teori, konsep serta membangun knstruksi teori baru.

\section{HASIL DAN PEMBAHASAN \\ Latar Belakang Mahasiswa Perantau Dari Jawa Membentuk Jong Java Di Undiksha}

1. Faktor kegelisahan

Kehidupan di dunia tidak selalu berjalan dengan baik sesuai dengan apa yang kita inginkan, apalagi di dalam kehidupan bermasyarakat. Di dalam lingkungan masyarakat banyak terdapat perbedaan-perbedaan yang tidak sesuai dengan karakter maupun budaya asli kita, perbedaan-perbedaan inilah yang terkadang menimbulkan rasa kurang nyaman pada diri individu, rasa kurang nyaman inilah yang biasanya disebut dengan kegelisahan. Kegelisahan atau yang biasa di kenal dengan kata gelisah merupakan suatu keadaan dimana seseorang individu merasakan kecemasan, ketakutan akan suatu hal tertentu sehingga berdampak suatu tindakan atau tingkah laku seseorang.

Hal seperti inilah yang dirasakan oleh para penggagas Paguyuban Jong Java kepada adik tingkat dan teman-temannya, karena sebuah kondisi lingkungan yang berbeda yaitu perbedan budaya dari budaya asli (Jawa) ke budaya baru (Bali) menyebabkan suatu sikap kurang nyaman sehingga mampu menyebabkan suatu keadaan kebingungan sosial atau Culture shock, Culture shock atau biasa kita kenal dengan gegar budaya merupakan sebuah istilah yang digunakan untuk menggambarkan perasaan gelisah, terkejut dan lain-lain yang keadaan tersebut terjadi apabila seseorang bersentuhan dengan kebudayaan baru di luar budaya kita seperti perbedaan cara beradaptasi, perbedaan budaya, perbedaan bahasa, dan perbedaan nilainilai sosial dan lain-lain, perbedaanperbedaan kebudayaan inilah yang membuat seseorang merasa gelisah karena keadaan yang kurang nyaman sehingga menyebabkan suatu tindakan yang bersifat negatif.

kegelisahan yang dialami oleh mahasiswa Jawa yaitu kepada perbedaan kebudayaan, perbedaan bahasa, dan nilainilai sosial masyarakat. Kegelisahan ini memang tidak dapat dipungkiri suatu kondisi yang berbeda dapat membuat kita mengalami kebingungan, dapat diketahui bahwasannya Bali sangat berbeda dengan Jawa dari segi apapun itu agama, budaya, bahasa dan lain-lain. Hal ini sesuai dengan apa yang diceritakan oleh salah satu informan peneliti yang bernama Faiz Abdullah, umur 24 Tahun berikut cerita yang di sampaikan kepada peneliti,

"Kerena berbeda bahasa, berbeda agama, berbeda kultur dan sosial masyarakat sehingga muncul kehawatiran mahasiswa Jawa terhadap keadaan lingkungan perantauan yaitu Bali, sebab adanya perasaan dan perbedaan itulah sehingga dibentuknya kelompok yang berasaskan kedaerahan yaitu Paguyuban Jong Java". Contoh dari adanya perbedaan yakni awal mula teman peneliti ingin merasa akrab 
dengan teman-temannya yang berasal dari Bali sehingga ia bertanya apa bahasa Balinya jalan-jalan, kemudian temannya menjawab melalong dan dengan polosnya teman peneliti berbicara dengan teman yang lainnya "hey ayok melalong" kemudian dengan kaget temannya memberi tahukan arti kata melalong yang sebenarnya, yaitu telanjang. Contoh lainnya yaitu jika di dalam Pura, kita tidak boleh berbuat aneh-aneh, karena Pura merupakan salah satu tempat suci bagi masyarakat Bali jika ada yang melanggar hal-hal tersebut maka akan dikenakan sanksi tersendiri bagipara pelanggar sesuai dengan kesalahannya yang dilakukan karena di setiap adanya aturan terdapat sanksi yang diberikan sesuai dengan kesalahan-kesalahan yang dilakukan.

\section{Faktor Kebutuhan}

Faktor lain yakni faktor kebutuhan dalam lingkungan bermasyarakat seorang individu dalam melakukan pemenuhan kebutuhan tidak bisa lepas dari orang lain, hal ini karena sejatinya manusia merupakan mahluk sosial. Kebutuhan sendiri berarti semua barang dan jasa yang dibutuhkan oleh individu dalam menunjang segala aktivitas yang dilakukan dalam kehidupan sehari-hari, kebutuhan sendiri dapat di bedakan menjadi beberapa sesuai dengan kebutuhan nya, seperti kebutuhan berdasarkan sifatnya di bagi menjadi dua yaitu kebutuhan jasmani dan kebutuhan rohani, kebutuhan jasmani yaitu kebutuhan dalam menjaga kesehatan fisik seperti olahraga, sedangkan kebutuhan rohani yaitu kebutuhan pemenuhan dalam jiwa seperti beribadah, jalan-jalan dan hiburan. Kebutuhan yang lain yaitu kebutuhan berdasarkan waktu, kebutuhan ini meliputi kebutuhan saat ini, masa depan, dan waktu yang tidak terduga, kebutuhan selanjutnya yaitu kebutuhan berdasarkan subjek yaitu pelaku, dalam kebutuhan ini terdapat dua poin yang masuk di dalam kebutuhan berdasarkan subjek, yaitu individu dan kelompok, kebutuhan individu sangat jelas yaitu untuk kebutuhan perorangan sedangkan kelompok yaitu untuk kebutuhan bersama atau untuk kepentingan masyarakat.

$\mathrm{Hal}$ ini sesuai dengan apa yang terjadi di dalam kelompok Paguyuban, adanya Paguyuban karena adanya kebutuhan entah itu kebutuhan individu maupun kelompok seperti kebutuhan sehari-hari. Seperti yang di jelaskan oleh informan peneliti yang bernama Arik Hariyanto umur 28 Tahun: "karena rasa membutuhkan antara satu mahasiswa dengan mahasiswa lain sehingga perlu adanya sebuah wadah yang mampu mempermudah para mahasiswa memenuhi kebutuhannya, entah kebutuhan dalam segi pribadi maupun umum dan biar pada saat membutuhkan kita sesama mahasiswa Jawa bisa saling tolong menolong sehingga lebih bisa mempererat tali persaudaraan sesama mahasiswa perantau. Adapun kebutuhan yang paling mendasar yaitu kebutuhan sehari-hari seperti meminjam sepeda motor untuk membeli makan dan kebutuhan lainnya yaitu perihal alat elektronik seperti laptop dan ATM, karena pada saat itu mahasiswa yang mempunyai alat-alat elektronik itu minim jadi yang tidak punya biasanya meminjam sama yang punya. Hal ini sesuai dengan apa yang terjadi di dalam kelompok Paguyuban, adanya Paguyuban karena adanya kebutuhan entah itu kebutuhan individu maupun kelompok seperti kebutuhan sehari-hari. Seperti yang di jelaskan oleh informan peneliti yang bernama Arik Hariyanto umur 28 Tahun: karena rasa membutuhkan antara satu mahasiswa dengan mahasiswa lain sehingga perlu adanya sebuah wadah yang mampu mempermudah para mahasiswa memenuhi kebutuhannya, entah kebutuhan dalam segi pribadi maupun umum dan biar pada saat membutuhkan kita sesama mahasiswa Jawa bisa saling tolong menolong sehingga lebih bisa mempererat tali persaudaraan sesama mahasiswa perantau. Adapun kebutuhan yang paling mendasar yaitu kebutuhan sehari-hari seperti meminjam sepeda motor untuk membeli makan dan kebutuhan lainnya yaitu perihal alat elektronik seperti laptop 
dan ATM, karena pada saat itu mahasiswa yang mempunyai alat-alta elektronik itu minim jadi yang tidak punya biasanya meminjam sama yang punya".

Pernyataan tersebut menunjukkan bahwasannya kebutuhan yang terjadi di dalam Paguyuban Jong Java bersifat mengikat sebab dampak yang diperoleh dari saling membutuhkan tersebut iyalah kemanfaatan dan dari adanya sikap saling membutuhkan secara tidak langsung dapat menjalin tali persaudaraan semakin erat.

Berdasarkan paparan diatas dapat diketahui bahwa faktor pembentuk Paguyuban Jong Java sesuai dengan syarat-syarat kelompok sosial. Hal ini sesuai dengan apa yang di jelaskan oleh Soedjono Soekanto (1990:123) bahwasanya di dalam kelompok sosial terdapat syarat-syarat kelompok sosial, jika dalam membentuk kelompok sosial tidak memperhatikan syarat-syarat tersebut maka kelompok sosial tidak akan terbentuk, karena syarat-syarat ini merupakan bagian penting saat ingin membentuk kelompok, adapun syaratsyarat kelompok sosial yang dimaksudkan yaitu adanya rasa memiliki kelompok tersebut, adanya hubungan timbal-balik antara anggota satu dengan anggota lain, adanya faktor yang membuat hubungan antar anggota terjalin erat dan lain-lain. Selain persamaan konsep mengenai syarat-syarat kelompok sosial menurut Soejono Soekanto, dalam syarat-syarat membentuk Paguyuban, terdapat perbedaan antara penelitian ini dengan kajian relevan yang digunakan sebagai kajian pustaka yaitu terletak pada syaratsyarat membentuk kelompok.

\section{Hubungan Sosial Mahasiswa Perantau di dalam Paguyuban Jong Java di Undiksha}

interaksi merupakan hubungan sosial yang bersifat dinamis seperti hubungan sosial yang terjadi antar mahasiswa perantau Jawa di Undiksha yang tergabung di dalam Paguyuban Jong Java mereka merupakan mahasiswa aktif yang berasal dari Jawa dan mencari ilmu di Bali yakni di Undiksha, meskipun meraka semua berasal dari Pulau Jawa akan tetapi etnis yang dimiliki oleh mahasiswa Jawa tidak semua beretnis Jawa akan tetapi ada yang beretnis Madura dan Sunda, mereka semua tergabung di dalam kelompok Paguyuban yang di namai Paguyuban Jong Java. Interaksi yang terjalin diantara mahasiswa perantau Jawa bisa dikatan berjalan dengan baik hal ini dapat dilihat bahwasannya antar mahasiswa perantau jika bertemu di jalan mereka akan saling menegur sapa Tidak hanya itu peneliti peneliti juga menemukan temuan pada saat peneliti melakukan observasi di salah satu tempat kos informan saat peneliti ingin melakukan wawancara kepada anggota Paguyuban yakni peneliti melihat ada teman yang datang ke kos sedang bermain dan kebetulan ada makanan, kemudia teman tersebut mengambil makanan pemilik kos tanpa bilang, kemudian pada saat pemilik kos datang teman tersebut baru bilang kalo sudah mengambil makanan yang ada di kamar kosnya, bahkan ada pula anak yang numpang tidur di kamar kos padahal posisi anak yang mempunyai kamar kos sedang tidak ada di kos, hal-hal tersebut merupakan tindakan yang dapat menunjukkan seberapa dekatnya hubungan yang terjalin di antara mereka. Proses interaksi sosial dapat terjadi apabila diantara dua individu dan kelompok terdapat kontak sosial dan komunikasi seperti interaksi di atas, interaksi di atas terjadi karena terpenuhinya dua syarat terjadinya interaksi sosial. Pertama, adanya kontak sosial yang melakukan hubungan sosial dengan individu lain, seperti yang dilakukan oleh Rita Defiana yang menyapa Nadhirotin dan mengajak berbincang serta melakukan kegiatan berjabat tangan, hal tersebut kemudian mendapat reaksi yang baik dari Nadhirotin yaitu Nadhirotin menjawab perbincangan dan membalas berjabat tangan tersebut. Kontak sosial yang terjadi antara Rita Defiana dan Nadhirotin merupakan kontak sosial antara individu dengan individu atau interaksi yang berbentuk perorangan. Kedua, dari terjadinya kontak sosial yang dilakukan di atas menghasilkan adanya komunikasi, komunikasi tersebut 
menggunkan bahasa tertentu, yakni bahasa yang digunakan yaitu Bahasa Jawa. Hal ini dikarenakan daerah Tuban dan Banyuwangi sama-sama beretnis Jawa. Pada dasarnya interaksi sosial memiliki bentuk-bentuk interaksi adapun dua bentuk dalam melakukan sebuah interaksi yaitu proses interaksi yang berbentuk asosiatif dan berbentuk disosiatif. Interaksi yang berbentuk asosiatif dapat menimbulkan sebuah bentuk kerjasama, contoh kerjasama yang terjadi di dalam Paguyuban Jong Java yaitu pada saat melaksanakan kegiatan satenan para anggota meluangkan waktu untuk bekerjasama menyiapkan keperluan yang dibutuhkan seperti bekerjasama membakar sate, bekerja sama memotong daging, membungkus nasi, membeli air dan kebutuhan lain yang diperlukan. Selain menimbulkan sebuah bentuk kerjasama proses interaksi berbentuk asosiatif juga menimbulkan proses akomodasi dan asimilasi. Proses akomodasi yang terjadi di dalam Paguyuban Jong Java yaitu dilakukan oleh ketua Paguyuban hal ini terjadi pada saat kegiatan diskusi bersama yang di ikuti oleh anggota dan pengurus terjadi perdebatan argumen mengenai tempat untuk dilaksanakannya kegiatan malam keakraban, kemudian ketua Paguyuban melakukan voting dengan memberikan tempat yang sudah di diskusikan, hal ini dilakukan karena jika terus dibiarkan saling memberikan argumen tentang pilihan tempat masing-masing maka tidak akan ada habisnya sehingga ketua Paguyuban melakukan voting sebagai cara untuk menyelesaikan permasalahan. Selain bentuk akomodasi juga terdapat bentuk asimilasi, bentuk asismilasi yang ada di Paguyuban Jong Java dapat kita lihat dari adanya kegiatan sosial seperti kegiatan 17 Agustus, kegiatan 17 Agustus ini dilakukan untuk memperingati hari kemerdekaan Negara Republik Indonesia dengan cara mengadakan perlombaan yang diikutioleh masyarakat kampung Jawa di Singaraja hal ini sebab Paguyuban Jong Java melakukan kegiatan berkoordinasi dengan RT/RW sekitar kampung Jawa dan lokasi kegiatanpun dilaksanakan di wilayah Kampung Jawa Kota Singaraja, sehingga kegiatan 17 Agustus ini terlaksana lebih meriah karena lomba yang dilaksanakan diikuti oleh beberapa anggota Paguyuban dan anak-anak yang ada di wilayah Kampung Jawa.

Adapun bentuk interaksi sosial kedua yaitu bentuk interaksi disosiatif, bentuk disosiatif ini merupakan interaksi yang mengarah pada sebuah perpecahan yang dapat membuat ikatan kekeluargaan kelompok merenggang, bentuk interaksi disosiatif berupa adanya persaingan, kontravensi dan pertentangan. Persaingan merupakan suatu proses sosial dimana individu maupun kelompok bersaing untuk mendapat keuntungan lewat keuntungan di bidang kehidupan tanpa mempergunakan kekerasan, sedangkan kontravensi merupakan suatu bentuk proses sosial yang berda diantara pertikaian, pertengkaran dan persaingan seperti menghasut, memfitnah, kegiatan kekerasan dan lain-lain dan pertikaian merupakan suatu proses sosial dimana individu atau kelompok menantang pihak lawan dengan cara ancaman kekerasan untuk memenuhi tujuannya. Jika dilihat dari pengertian di atas maka bentuk interaksi disosiatif ini tidak terjadi di dalam Paguyuban Jong Java karena Paguyuban Jong Java merupakan kelompok yang mengutamakan tali persaudaraan sehingga apapun yang dilakukan oleh para anggota semata-mata untuk kebaikan bersama sehingga suatu proses untuk merugikan anggota yang lain tidak terjadi pada para anggota Paguyuban Jong Java dan suatu permasalahan atau konflik tidak terjadi di antara anggota Paguyuban. Memang jika kita lihat hidup di masyarakat apalagi berkelompok tidak mungkin tidak terjadi konflik, akan tetapi konflik yang terjadi hanya bersifat biasa atau kecil sehingga tidak sampai menimbulkan suatu perdebatan sengit yang menyebabkan pertengkaran, konflik yang di maksudkan seperi pada saat kegiatan diskusi atau musyawarah terjadi perbedaan pendapat, perbedaan pilihan, perbedaan-perbedaan tersebut hanya bersifat sementara yaitu konflik tersebut 
hanya terjadi pada saat diskusi saja setelah diskusi selesai perdebatan tersebut selesai dan keadaan tersebut merupakan suatu hal yang wajar di dalam suatu kelompok pada saat kegiatan diskusi ataupun musyawarah.

Secara sosiologis di dalam hubungan sosial terdapat bentuk-bentuk interaksi sosial. Menurut Soejono Soekanto (1994:76-97) bahwa di dalam proses hubungan sosial terdapat dua bentuk interaksi yaitu bentuk asosiatif dan bentuk disosiatif, dengan adanya bentuk interaksi sosial tersebut dapat menumbuhkan rasa solidaritas yang tinggi di dalam kelompok sosial. Selain persamaan konsep mengenai bentuk-bentuk interaksi sosial di dalam hubungan sosial menurut Soejono Soekanto, dalam bentuk interaksi yang terjadi di dalam penelitian ini terdapat perbedaan dengan kajian relevan yang digunakan sebagai kajian pustaka yakni terletak pada bentuk adaptasi yang dilakukan oleh penelitian terdahulu, penelitian terdahulu menjelaskan tentang adaptasi yang di lakukan sedangkan penelitian ini menjelaskan tentang bentuk interaksi yang terjadi di dalam Paguyuban Jong Java di Undiksha

\section{Peran Jong Java Terhadap Mahasiswa Perantau Di Undiksh}

Peran merupakan suatu proses menjalankan hak dan kewajibannya sesuai dengan sataus yang di miliki, seperti halnya Paguyuban Jong Java. Paguyuban Jong Java memiliki struktur kepengurusan yang di dalamnya terdapat lurah, carik, dan Kaur, status tersebut memiliki peran masing-masing di dalam Paguyuban Jong Java. Hal ini agar mempermudah para pengurus Paguyuban dalam menjalankan hak dan kewajibannya maka di bentuknya program kerja yang dintaranya terdapat program kerja yang berhubungan dengan kesejahteraan anggota dan kehidupan sosial. Paguyuban Jong Java dalam mensejahhterakan anggota melalui berbagai kegiatan seperti saling melengkapi kebutuhan, seperti saling membutuhkan perihal barang maupun jasa dan sebagai tempat berkumpul. Sedangkan adanya program kerja dalam kehidupan sosial yaitu untuk meningkatkan solidaritas yang terjadi dalam membina hubungan yang baik dengan anggota Paguyuban yang lain, yaitu sebagai tempat diskusi oleh para anggota Paguyuban Jong Java. Peran dari Paguyuban Jong Java dapat membantu mempermudah kehidupan para anggota, mulai dari mempermudah mencari teman atau sebagai tempat berkumpul, mempermudah memenuhi kebutuhan, mempermudah kehidupan bersosial atau berdiskusi dan lain sebagainnya. Hal ini sesuai dengan yang di katakana oleh salah satu anggota Paguyuban yang bernama M Iman Ghozali mahasiswa Jawa yang berasal dari Jember, umur 23 Tahun:"saya dari Jember sendirian, saya enggak punya temen kemudian pas saya disini ada kakak tingkat dari Lamongan mengajak saya untuk bergabung di dalam Paguyuban Jong Java dan kemudian dari Paguyuban Jong Java itu saya kenal sama anak-anak Jawa yang lain dan dari sana saya punya teman, jadi adanya Paguyuban ini membantu saya untuk mencari temen". Di dalam Paguyuban Jong Java terdapat aturan bahwasannya yang menjadi anggota Paguyuban Jong Java hanya mahasiswa yang berasal dari Jawa dan mahasiswa yang masih memiliki keturunan Jawa, jika bukan dari mahasiswa yang berasal dari Jawa dan tidak memiliki keturunan Jawa maka mahasiswa tersebut tidak diperbolehkan bergabung di dalam Paguyuban Jong Java, adapaun yang dimaksudkan berasal dari Jawa dan memiliki keturunan Jawa bukan pada etnis, tetapi wilayah kepulauan Jawa. Hal ini sesuai dengan yang dikatakan oleh Arik Hariyanto umur 28 Tahun, ia berkata

"Anggota Paguyuban Jong Java memiliki aturan, yakni mereka yang berasal dari pulau Jawa dan masih memiliki keturunan Jawa, karena Paguyuban ini di bentuk untuk mahasiswa Jawa sehingga anggotanya pun harus dari Jawa, jika tidak ada jawa-jawanya maka tidak di perbolehkan bergabung". Secara teori peran Paguyuban Jong Java di atas dapat di kaitkan dengan konsep menurut Soejono Soekanto (2002:286-289) yakni 
peran merupakan suatu tindakan yang dilakukan oleh kelompok atau individu untuk kehidupan masyaraka, peran menekankan sebagai suatu proses, penyesuaian diri, dan fungsi. Peran menurut Soejono Soekanto (2002:246) terdapat beberapa hal yang mencakup sebagai peranan, yaitu peranan dapat dikatakan sebagai prilaku yang penting bagi sesama anggota Paguyuban dan peranan yang merupakan rangkaian aturan yang terlaksana demi kebaikan kehidupan di dalam Paguyuban Jong Java. Selain sesuai dengan konsep mengenai peran Paguyuban Jong Java menurut Soejono Soekanto, dalam peran Paguyuban Jong Java yang terjadi di dalam penelitian ini terdapat perbedaan dengan kajian relevan yang digunakan sebagai kajian pustaka yakni terletak pada aturan dan peran yang dilaksanakan di dalam Paguyuban Jong Java di Undiksha.

\section{Aspek-Aspek Paguyuban Jong Java Yang Dijadikan Sebagai Sumber Belajar Sosiologi}

1. Ranah Kognitif

Ranah kognitif yaitu merupakan aspek yang berkaitan dengan pengetahuan, penalaran dan pikiran. Dalam kaitannya dengan $\mathrm{KI} 3$ yang sesuai dengan silabus Kementrian Pendidikan dan Kebudayaan Jakarta 2016) yaitu memanfaatkan hasil penelitian tentang mahasiswa rantau dalam Paguyuban Jong Java di Undiksha sebagai sumber belajar sosiologi di SMA, yaitu siswa dapat memahami, menerapkan, serta dapat menganalisisi alasan yang berkaitan dengan latar belakang mahasiswa perantau membentuk Paguyuban Jong Java di Undiksha, bagaimana hubungan sosial yang terjadi antar mahasiswa perantau yang tergabung di dalam Paguyuban Jong Java di Undiksha dan bagaimana peran Paguyuban Jong Java di Undiksha terhadap anggota.

\section{Ranah Afektif}

Ranah afektif yaitu merupakan aspek yang berkaitan dengan sikap perasaan, emosi, dan reaksi yang berbeda dengan penalaran. Hal ini ini sesuai dengan apa yang ada pad Kompetensi Inti (KI) I dan II. Dalam menjelaskan mengenai KI I dan 2 di atas, menegaskan bahwa pemanfaatan hubungan sosial mahasiswa perantau dalam Paguyuban Jong Java di Undiksha sebagai sumber belajar sosiologi di SMA dapat dikaitkan dengan materi individu, kelompok dan hubungan sosial, di mana siswa dapat memperoleh pemahaman bahwasannya hubungan sosial mahasiswa perantau dalam Paguyuban ini dapat di jadikan contoh dari materi Individu, kelompok dan hubungan sosial pada sub materi bentuk interaksi silaturahmi, silaturahmi sendiri merupakan suatu kegiatan di mana sesama manusia harus saling menjalin hubungan yang baik sehingga dengan adanya kegiatan silaturahmi maka hubungan kita sesama manusia akan bertahan kekal, karena sejatinya semua umat manusia di dunia ini adalah keluarga jika dilihat dari silsila keluarga maka kita akan mengetahui bahwasannya kita berasal dari nenek moyang yang sama, di dalam agama juga di ajarkan untuk menjalin silaturrahmi yang baik sesama manusia karena kita semua adalah saudara tidak hanya silaturahmi saja yang dapat di jadikan sebagai contoh dari materi individu, kelompok dan hubungan sosial akan tetapi kerjasama juga dapat di jadikan sebagai contoh, hal ini karena kerjasama merupakan suatu kegiatan di mana sesama manusia harus saling tolong menolong dalam hal apapun. Sedangkan dalam kaitannya dengan $\mathrm{KI} 2$, peserta didik mendapatkan pembelajaran untuk lebih perduli dan terbuka dengan sesama, seperti halnya kegiatan yang ada di dalam Paguyuban Jong Java di Undiksha, walaupun sudah ada panitia yang bertugas untuk menyiapkan kebutuhan-kebutuhan kegiatan akan tetapi sebagai anggota yang bergabung di dalam Paguyuban maka secara tidak langsung akan ikut serta membantu menyiapkan kebutuhan-kebutuhan yang kurang, hal ini karena kita sebagai anggota Paguyuban memiliki rasa bahwasannya Paguyuban ini milik kita bukan milik yang lain dan karena hubungan yang terjadi di dalam Paguyuban sudah seperti saudara sendiri,dan dalam hal ini Peserta didik juga mendapatkan pembelajaran untuk lebih bersikap saling menghargai satu 
sama lain atau yang biasa di sebut dengan sikap toleransi, sebab anggota Paguyuban Jong Java terdiri dari berbagai etnis atau budaya sehingga agar mencapai tujuan bersama maka di butuhkannya sikap toleransi atau menghargai etnis yang berbeda antara anggota satu dengan anggota lain.

3. Ranah Psikomotor

Ranah yang terakhir adalah ranah psikomotor, ranah ini menggunakan aspek keterampilan jasmani. Ranah psikomotor ini jika dikaitkan dengan kurikulum 2013 sesuai dengan $\mathrm{KI} 4$, di mana penjelasan $\mathrm{KI}$ 4. Dalam kaitannya dengan $\mathrm{KI} 4$ dengan hubungan sosial mahasiswa perantau di dalam Paguyuban Jong Java sebagai sumber belajar sosiologi di SMA, yaitu peserta didik diharapkan mampu untuk mengaitkan realita sosial dengan menggunakan konsep-konsep dasar sosiologi untuk menggali beberapa bentuk hubungan sosial di masyarakat. dalam penjelasan mengenai aspek-aspek di atas, penelitian ini mempunyai potensi sebagai sumber belajar sosiologi di SMA kelas $X$ dalam materi individu, kelompok dan hubungan sosial, adapun potensi yang di maksud yaitu penjelasan yang dipaparkan dalam bentuk Rancangan Pelaksanaan Pembelajaran (RPP)

\section{SIMPULAN DAN SARAN}

Dari penelitian yang peneliti lakukan tentang Hubungan Sosial Mahasiswa Perantau Dalam Paguyuban Jong Java Sebagai Sumber Belajar Sosiologi Di Sma (Studi Kasus Paguyuban Jong Java Di Undiksha), maka dapat disimpulkan sebagai berikut:

1. Faktor kegelisahan dan faktor kebutuhan, faktor kegelisahan ini ada sebab adanya perbedaan, seperti yang dapat diketahui bahwa Jawa itu berbeda dengan Bali, dari segi bahasa, dari segi agama, dan dari segi yang lain-lain sehingga dapat memunculkan suatu rasa takut atau gelisah yang menyebabkan kecemasan bagi mahasiswa itu sendiri sehingga dengan adanya Paguyuban Jong Java ini mampu meminimalisir rasa kegelisahan tersebut. Faktor lainnya yaitu kebutuhan, sesungguhnya manusia hidup itu pasti akan membutuhkan orang lain dari rasa saling membutuhkan tersebutlah yang menjadikan kita secara tidak langsung berhubungan dengan orang lain untuk memenuhi kebutuhan kita, sehingga dari rasa saling membutuhkan inilah Paguyuban Jong Java.

2. Paguyuban Jong Java terdapat berbagai kegiatan yang digunakan agar hubungan yang terjalin menimbulkan rasa solidaritas yang tinggi, adapun kegiatankegiatan yang dapat menjadikan sebuah hubungan itu semakin akrab yaitu kegiatan diskusi, kegiatan perayaan harihari besar islam dan hari-hari besar umum, lewat kegiatan ini akan mampu menyatukan anggota-anggota Paguyuban karena kegiatan yang dilaksanakan oleh Paguyuban akan terjadi hubungan sosial berbentuk kerjasama, akomodasi, asimilisi dan lain-lain.

3. Peran yang dimiliki Paguyuban Jong Java yakni sebagai tempat untuk memenuhi kebutuhan, kebutuhan yang dimaksud yaitu kebutuhan mencari teman, mencari tempat tinggal/kos, dan lain-lain. Peran Paguyuban Jong Java tidak hanya sebagai pemenuhan kebutuhan saja akan tetapi sebagai tempat berkumpul dan sebagai tempat diskusi, diskusi perihal apapun yang menjadi keingintahuan anggota-anggota yang lain.

4. Dari hasil penelitian ini, memiliki potensi sebagai sumber belajar sosiologi di SMA. Adapun aspek-aspek dalam penelitian ini yang digunakan untuk membahas hasil penelitian yang memiliki potensi sebagai sumber belajar sosiologi yakni ada tiga, yaitu ranah kognitif, ranah afektif, dan ranah psikomotor, dengan menggunakan aspek-aspek tersebut dapat mengetahui hasil penelitian yang berpotensi sebagai sumber belajar dalam bentuk RPP dengan menggunakan materi tentang imdividu, krlompok dan hubungan sosial.

Berdasarkan hasil penelitian yang dilakukan oleh peneliti di lapangan, ada beberapa temuan yang ingin disampaikan penulis sebagai terkait dengan penelitian yang dilakukan, yaitu

a. Bagi guru, dengan menggunakan sumber belajar yang monoton sehingga dapat membuat peserta didik 
tidak dapat memahami sumber yang lain sehingga rasa keingin tahuannya tidak berkembang. Seharusnya dalam kegiatan belajar mengajar guru dapat memberikan contoh yang berada di sekitar siswa agar siswa dapat memahami dan mempunyai kepekaan terhadap lingkungan sekitarnya.

b. Bagi peserta didik, di harapkan tidak hanya berfokus pada sumber belajar seperti buku paket dan LKS tetapi peserta didik harus lebih dekat dengan lingkungan sekitar agar tidak mengabaikan fenomena-fenomena sosial yang ada di lingkungan tempat tinggal utamnnya, sehingga pemahaman peserta didik tidak hanya itu-itu saja.

\section{UCAPAN TERIMAKASIH}

Beribu-ribu kata syukur saya ucapkan kepada Allah SWT, karena sudah mengabuklan segala do'a yang saya panjatkan. Terimakasih kepada Orang Tua Tercinta dan keluarga saya, terima kasih atas pengorbanan, dukungan, semangat, kasih sayang yang telah kalian berikan selama ini serta doa yang tiada henti untuk kesuksesan saya, karena tiada doa yang paling mustajab selain doa yang terucap dari orang tua dan keluarga. Ucapan terimakasih saja takkan pernah cukup untuk membalas kebaikan orang tua dan keluarga, maka dari itu terimalah persembahan bakti dan kasih ku untuk kalian dan Karena berkat kalian saya bisa menyelesaikan pendidikan saya sampai pada perguruan tinggi yang tak pernah terbayangkan sebelumnya.

\section{DAFTAR PUSTAKA}

Soekanto, Soerjono. 2002. Sosiologi

Suatu Pengantar. Jakarta: PT.

Raja Grafindo Persada.

Soekanto, Soerjono. 1990. Sosiologi

Suatu Pengantar. Jakarta: PT Raja

Grafindo Persada.

Kamus besar bahasa Indonesia edisi ke

empat. 